Gut, 1984, 25, 1372-1375

\title{
Evaluation of indium scintigraphy in patients with active inflammatory bowel disease
}

\author{
M S BUXTON-THOMAS, R J DICKINSON, P MALTBY, \\ J O HUNTER, AND E P WRAIGHT \\ From the Departments of Nuclear Medicine and Medical Gastroenterology, Addenbrooke's Hospital, \\ Cambridge
}

SUMMARY Recent reports have indicated a possible role for ${ }^{111}$ Indium leucocyte scintigraphy in the management of patients with acute inflammatory bowel disease. Our experience with this technique in 15 patients (nine with ulcerative colitis, six with Crohn's disease) is described. Perfect agreement was not obtained between scintigraphic appearances and other conventional means in the assessment of extent of disease. Good correlation, however, was found between disease activity and recovery of labelled leucocytes in the faeces. While this latter finding could be used as an objective means of assessing response to therapy, it is concluded that conventional indium scintigraphy, using indium oxine-labelling of mixed leucocytes, is insufficiently reliable to replace usual methods for determining extent of disease in patients with inflammatory bowel disease.

Recent reports from the $\mathrm{UK}^{12}$ and $\mathrm{USA}^{3}$ have indicated a possible role for ${ }^{111}$ Indium leucocyte scintigraphy in the management of patients in exacerbation of chronic inflammatory bowel disease. The migration of labelled leucocytes to the areas of active inflammation enables scintigraphic estimation of the extent of the disease while its severity is related to the proportion of the leucocyte label which is shed in the faeces. This report describes the findings in our evaluation of the technique.

\section{Methods}

\section{PATIENTS}

Fifteen consecutive inpatients who were admitted in exacerbation of chronic inflammatory bowel disease were included in the study. Each gave informed consent to the intended investigation. Six patients had Crohn's disease and nine had ulcerative colitis diagnosed according to conventional critieria.

\section{SEVERITY OF DISEASE}

Disease severity was estimated on admission of the patient to hospital according to the criteria of

Address for correspondence: Dr M Buxton-Thomas, Department of Nuclear Medicine, Addenbrooke's Hospital, Hills Road, Cambridge CB2 $2 \mathrm{QQ}$.

Received for publication 21 February 1984
Truelove and Witts ${ }^{4}$ or the Crohn's disease activity index (CDAI). ${ }^{5}$

EXTENT OF DISEASE

The results of the four hour ${ }^{111}$ Indium scintigrams were compared with those obtained by conventional radiological or endoscopic techniques or, in some instances, by inspection of resected specimens. No attempt was made to correlate scintigraphic findings with histological appearances and the comparisons were based on the gross macroscopic or radiological appearances only (Table). In two patients (no 4 and 11, Table) limited colonoscopy was performed because of the severity of their disease. In each instance the colonoscope was passed to the splenic flexure and it was only possible therefore to confirm left sided disease in these patients. Although the disease might have extended further for the purposes of comparison it was assumed that the disease did not extend proximal to the splenic flexure. One patient (patient 1, Table) did not have conventional assessment during her admission. In this instance it was assumed that the disease was restricted to the left hemicolon as had been shown in four previous barium enemas and was reconfirmed in a subsequent outpatient examination.

TREATMENT RECEIVED

All- the patients were given active treatment on admission to hospital which included replacement of 
Table Clinical details of patients

\begin{tabular}{|c|c|c|c|c|c|c|c|c|}
\hline \multirow[b]{2}{*}{ No } & \multirow[b]{2}{*}{ Diagnosis } & \multicolumn{3}{|l|}{ Extent of disease } & \multirow{2}{*}{$\begin{array}{l}\text { Activity } \\
\text { in stools } \\
(\%)\end{array}$} & \multirow[b]{2}{*}{$\begin{array}{l}\text { Severity } \\
\text { of disease }\end{array}$} & \multirow{2}{*}{$\begin{array}{l}\text { Treatment } \\
\text { at time of } \\
\text { scintigram } \\
\text { (days) }\end{array}$} & \multirow[b]{2}{*}{$\begin{array}{l}\text { Treatment } \\
\text { (Pred) }\end{array}$} \\
\hline & & $\begin{array}{l}\text { Conventional } \\
\text { means }\end{array}$ & $\begin{array}{l}\text { Test used and } \\
\text { days post scint }\end{array}$ & $\begin{array}{l}\text { Indium } \\
\text { scintigram }\end{array}$ & & & & \\
\hline 1 & $\mathrm{CD}$ & $\begin{array}{l}\text { Patchy, } \\
\text { L sided }\end{array}$ & Barium enemas* & Negative & $1 \cdot 7$ & $\mathrm{CDAI}=421$ & 5 & $\begin{array}{l}10 \mathrm{mg} \\
\text { ED }\end{array}$ \\
\hline 2 & $\mathrm{CD}$ & Total & Colectomy 11 & Total & $26 \cdot 5$ & Severe & 6 & $40 \mathrm{mg}$ \\
\hline 3 & UC & Total & Barium enema 14 & Total & $18 \cdot 4$ & Severe & 4 & $40 \mathrm{mg}$ \\
\hline 4 & UC & $\geqslant \mathrm{L}$ sided & Colonoscopy 13 & L sided & 61 & Severe & $>14$ & $30 \mathrm{mg}$ \\
\hline 5 & $\mathrm{CD}$ & $\begin{array}{l}\mathrm{R} \text { sided with } \\
\text { perianal fistulae }\end{array}$ & Colectomy 14 & Rectal & $2 \cdot 8$ & Severe & 0 & $\begin{array}{l}\text { Bowel/rest } \\
\text { TPN }\end{array}$ \\
\hline 6 & UC & L sided & Colonoscopy 1 & L sided & 10 & Severe & $>14$ & $30 \mathrm{mg}$ \\
\hline 7 & UC & Total & Barium enema -5 & Total & 24 & Severe & 7 & $40 \mathrm{mg}$ \\
\hline 8 & UC & $\mathrm{L}$ sided & Colonoscopy 6 & L sided & 37 & Severe & 6 & $40 \mathrm{mg}$ \\
\hline 9 & $\mathrm{UC}$ & Total & Barium enema 4 & Caecum & 7 & Severe & 10 & $40 \mathrm{mg}$ \\
\hline 10 & $\mathrm{CD}$ & $\mathrm{R}$ sided & Barium enema 8 & $\mathbf{R}$ sided & 19 & $\mathrm{CDAI}=303$ & 0 & ED \\
\hline 11 & UC & $\geqslant \mathrm{L}$ sided & Colonoscopy 2 & $\mathbf{R}$ sided & - & Severe & $<14$ & $40 \mathrm{mg}$ \\
\hline 12 & $\mathrm{CD}$ & Total & Barium enema 12 & Total & 31 & $\mathrm{CDAI}=268$ & 5 & $40 \mathrm{mg}$ \\
\hline 13 & UC & L sided & Colonoscopy 1 & Focal & 25 & Severe & $>14$ & $10 \mathrm{mg}$ \\
\hline 14 & $\mathrm{CD}$ & Terminal ileum & Surgery 10 & $\begin{array}{l}\text { Terminal } \\
\text { ileum }\end{array}$ & $10 \cdot 6$ & $\mathrm{CDAI}=194$ & $>14$ & $30 \mathrm{mg}$ \\
\hline 15 & UC & Total & Barium enema $-9 \dagger$ & Rectal & 21 & Severe & $>14$ & $40 \mathrm{mg}$ \\
\hline
\end{tabular}

* Barium enemas performed before and after this exacerbation showed left sided disease.

† Subsequent colectomy showed no evidence of disease proximal to the sigmoid colon.

Pred $=$ Prednisolone. ED $=$ Element Diet. TPN $=$ Total Parenteral Nutrition.

blood and fluids where necessary. In addition 13 patients received corticosteroids. Of these one patient (no 1, Table) was continued on a small dose of prednisolone which she had been taking long term and given an elemental diet while six patients (nos $4,6,12,13,14,15)$ were maintained on high dose prednisolone which had been initiated in the outpatient department. Two patients (nos 5 and 10) received total parenteral nutrition and an elemental diet respectively as primary therapy and did not receive corticosteroids. All the patients (except nos 5 and 10 ) had been receiving active therapy for a minimum of four days at the time the scintigrams were performed.

\section{SCANNING TECHNIQUE}

Sixty millilitres of blood were withdrawn from each patient and after separation the white cells obtained were labelled using indium oxine kits supplied by Amersham International according to their protocol. ${ }^{6}$ The labelled cells were then injected intravenously and imaging carried out using an Elscint double headed whole body scanner. Anterior and posterior images were obtained at four and 24 hours. Disease extent was assessed on the four hour scintigrams.

Stools were collected and counted from each patient for three days after injection of the labelled cells and the percentage activity of the total dose injected was calculated.

\section{Results}

Fifteen patients were studied and details are given in the Table. Stool activity was counted in 14 of the 15 patients and was greater than $2 \%$ in all but one instance thus confirming disease activity. ${ }^{1}$ Scintigraphic agreement was obtained in nine patients (see Fig. 1). The scintigrams, however, underestimated the gross extent of disease in six instances (Fig. 2).

In one patient (no 15) in whom there was a marked discrepancy between the scintigraphic and radiological findings subsequent colectomy showed no evidence of disease proximal to the sigmoid colon in spite of prior radiological evidence to the contrary.

\section{Discussion}

These results show that while the recovery of labelled leucocytes in the faeces reliably correlates with conventionally derived indices of disease activity in patients with active ulcerative colitis or Crohn's disease, indium scintigraphy is not an entirely reliable method of estimating disease extent. The failure to obtain correlation between conventional and scintigraphic means might be explicable either by the effect of steroid therapy on the kinetics of the ${ }^{111}$ Indium labelled white cells or by therapeutic reduction of the disease activity. ${ }^{2}$ In 


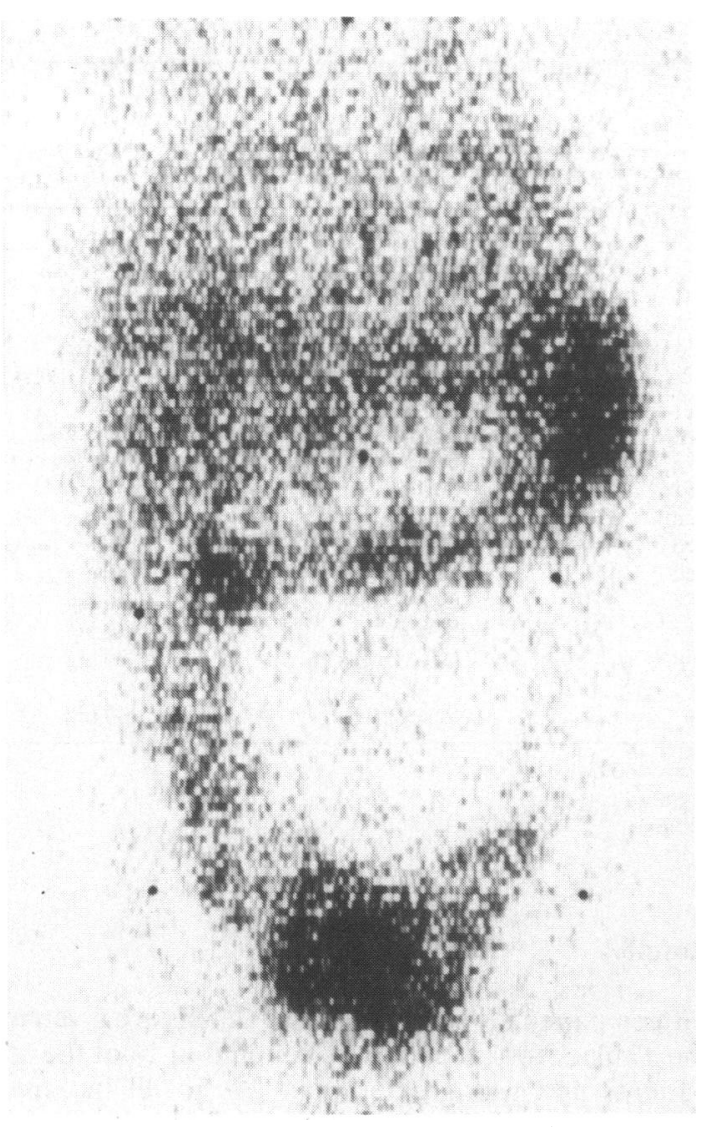

Fig. 1 Four hour indium scintigram showing total colitis (Patient no 3).

this regard it is notable that of the discrepant scintigrams two were in patients with low stool counts and it might be that these results related to low disease activity in spite of clinical evidence of active disease. This explanation alone, however, would not account for the other discrepant results nor can the effects of steroids be necessarily implicated in view of the positive scans obtained in the other patients on high dose steroids. Notwithstanding any theoretical explanation for our results if indium scintigraphy is to assume a place in the management of the patient with ulcerative colitis or Crohn's disease, it will have to prove itself reliable in those acutely ill patients receiving active therapy.

Although the previous studies of indium scintigraphy have reported good results they have also failed to obtain correlation between the scintigraphic and conventional means of assessment of extent of disease in all the patients. ${ }^{1-2}$ These results taken with those reported here show that indium scintigraphy cannot be entirely relied upon to give an accurate assessment of the disease extent. Our data, however, confirm that the recovery of leucocytes from the faeces may provide a reliable quantitative estimate of disease activity although it is notable that indium labelling is no more accurate in this regard ${ }^{3}$ than the conventional clinical criteria on which therapeutic decisions will depend.

New labelling techniques, however, have since been developed using indium acetyl acetonate and indium tropolonate. Comparisons have shown that labelling either crude or pure granulocytes in plasma with ${ }^{11}$ Indium tropolonate gives high labelling efficiency with minimal alteration in cell behaviour. ${ }^{9}$ These techniques may therefore result in better assessment of disease extent and may indeed supersede conventional criteria for accurate assessment.

Indium scintigraphy is expensive with long labelling procedure and our findings show that it is insufficiently reliable to replace conventional methods of clinical assessment. While it has research interest and may provide objective means of assessing response to therapy, it has no advantages to warrant its routine use in patients with inflammatory bowel disease. 


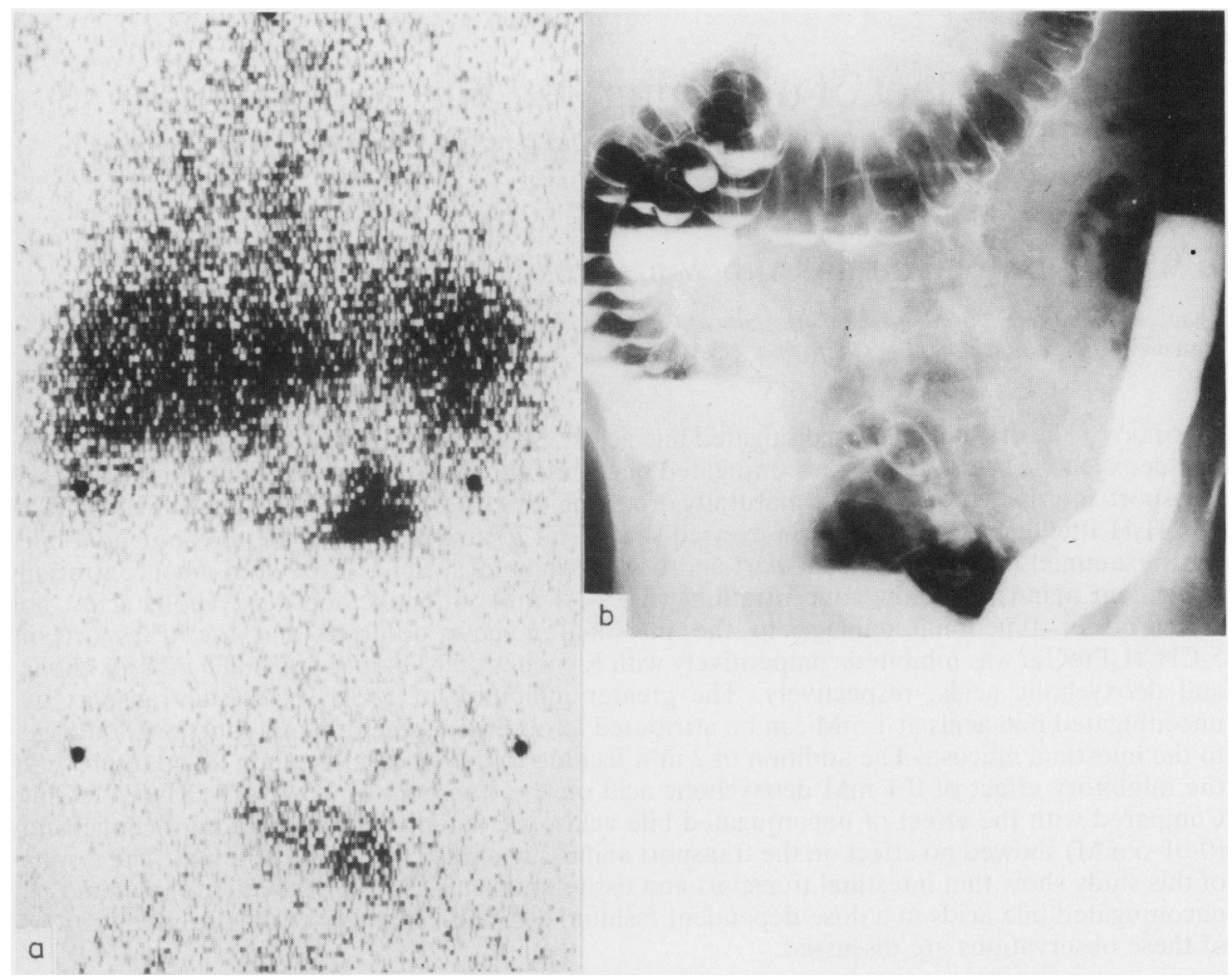

Fig. 2 (a) Four hour indium scintigram showing focal activity at splenic flexure (Patient no 13). Colonoscopy showed inflammatory polyposis at this site and active colitis distally. (b) Barium enema from the same patient showing a left sided colitis.

\section{References}

1 Segal AW, Ensell J, Munro JD, Sarner M. Indium-111 tagged leucocytes in the diagnosis of inflammatory bowel disease. Lancet 1981; 2: 230-2.

2 Saverymuttu SH, Peters AM, Hodgson HJ, Chadwick VS, Lavender JP. Indium-111 autologous leucocyte scanning: comparison with radiology for imaging the colon in inflammatory bowel disease. $\mathrm{Br}$ Med J 1982; 285: 255-7.

3 Stein DT, Gray GM, Gregory PB, Anderson M, Goodwin DA, McDougall IR. Location and activity of ulcerative and Crohn's colitis by Indium 111 leukocyte scan. A prospective comparison study. Gastro- enterology 1983; 84: 388-93.

4 Truelove SC, Witts LJ. Cortisone in ulcerative colitis. Final report on a therapeutic trail. $\mathrm{Br} M e d \mathrm{~J}$ 1955; 2: 1041-8.

5 Best WR, Bectel JM, Singleton JW, Kern F Jr. Development of a Crohn's disease activity index. National Cooperative Crohn's Disease Study. Gastroenterology 1976; 70: 439-44.

6 Amersham Int. plc 1983 Indium $\left({ }^{111}\right.$ In) Oxine solution for cell labelling.

7 Saverymuttu SH, Peters AM, Danpure HJ et al. Lung transit of ${ }^{111}$ Indium labelled granulocytes. Relationship to labelling techniques. Scand J Haematol 1983; 30: $151-60$. 